\title{
"OTHERING MaISIE": Pelos Olhos de Maisie e a estética JAMESIANA DA ALTERIDADE*
}

\section{DOROTHY J. HALE}

Universidade da Califórnia

Resumo:

Ao analisar o romance Pelos olhos de Maisie (What Maisie Knew), Hale discute como a opção narrativa de Henry James pela técnica do ponto de vista e pelas exigências da economia artística podem conduzi-lo a dificuldades éticas e políticas na representação do Outro, que muitas vezes parece na iminência de dissolver-se numa versão do próprio autor - ou, dizendo de outro modo, tomando por base a representação da alteridade como valor social da arte na tradição anglo-americana, ela verifica em que medida o projeto estético de James comprometeria seu projeto ético.

\section{Abstract:}

Through an analysis of the novel What Maisie Knew, the author explores how Henry James's choice of the tecnique of the point of view, along with the demands of the artistic economy, generate ethical and political difficulties for the novel's representation of the Other, who often seems on the verge of dissolving into a version of the author. In other words, based on the idea in the AngloAmerican tradition of the representation of alterity as the social value of art, the paper examines to what extent James's aesthetic project might jeopardize his ethical project.
Palavras-chave:

Henry James; realismo; ponto de vista; ética; alteridade.

\footnotetext{
Keywords:

Henry James; realism; point of view; ethics; alterity.
}

\footnotetext{
* Palestra promovida pelo Departamento de Teoria Literária e Literatura Comparada e proferida na Faculdade de Filosofia, Letras e Ciências Humanas (Universidade de São Paulo) em 20 de maio de 2013. Tradução: Ana Carolina Mesquita e Revisão da tradução: Marcelo Pen Parreira
} 
Em Playing in the Dark (1992), Toni Morrison inicia seu estudo sobre a "branquitude ${ }^{1} \mathrm{e}$ a imaginação literária" nos Estados Unidos com uma provocação sobre a mudança que, para ela, sua conversão em escritora provocou em sua experiência como leitora:

Como leitora (antes de virar escritora), eu lia conforme haviam me ensinado a ler.
Porém, como escritora, os livros se revelaram bastante diferentes para mim. Nessa
atividade necessito de uma enorme confiança na capacidade de imaginar os outros e
na disposição de projetar-me conscientemente nas zonas de perigo que tais outros
podem representar para mim. ${ }^{2}$

Intuitivamente faz sentido a distinção proposta por Morrison entre ler como escritora de ficção (criadora de personagens) e ler como leitora (socialmente disciplinada). No século XIX, em especial, com a consolidação do romance realista na Grã-Bretanha, era comum entre os escritores a crença de que a chave para um romance bem-sucedido residia na capacidade criativa de vivenciar como indivíduos reais os personagens por eles inventados. Um exemplo é Anthony Trollope, que de modo célebre associa projeto de escrita ficcional a êxito do autor em trazer à vida as criações "de sua cabeça", de modo que "falem e se movimentem como criaturas humanas" para seus leitores. ${ }^{3}$ Trollope chega a afirmar que o êxito de um romance depende da capacidade do autor, em seu ato criativo, de estabelecer relações reais e interpessoais com seus personagens fictícios - convivendo com eles "na realidade plena da intimidade estabelecida. Ele deve aprender a odiar e a amar junto com eles. Deve discutir, brigar, perdoar e até mesmo submeter-se a eles. (...) A profundidade e o alcance, a mesquinhez e a superficialidade de cada um devem estar claras para o autor". ${ }^{4}$

A ideia de que o sucesso artístico de um romance está relacionado tanto à relação emocional verdadeira que um escritor estabelece com seus personagens fictícios quanto com a relação social que acredita ter com eles era tão difundida no século XIX que até mesmo um autor como Thackeray, satisfeito em assumir o papel de titereiro na feitura de seus romances, descreve o processo criativo como uma inversão das relações de poder, na qual os personagens controlam o autor. Em carta, Thackeray afirma que após terminar um livro, sentia-se "como uma estalagem vazia e tinha saudades das pessoas (...) que se hospedaram comigo durante vinte meses! Elas perturbaram meu descanso; atormentaram-me a cada minuto: atiraram-se sobre mim quando eu estava doente, ou quando desejava descansar...". 5 Aqui, é o autor que está sempre à disposição de seus indivíduos imaginários. Estes são descritos por Thackeray como possuidores de uma presença não muito distinta daquela dele mesmo, a tal ponto que sente como se também possuíssem um estatuto social superior: ele é o estalajadeiro; eles, os hóspedes exigentes a quem deve servir. De fato, como seres sociais, os personagens são tão vívidos e tão bem-sucedidos em seu domínio sobre Thackeray que, na lógica figurativa do autor, a humanidade de seus heróis reduz a sua própria a uma casca oca: na descrição de

1 Embora não esteja oficialmente dicionarizado, o termo "branquitude" (whiteness, no original) vem sendo utilizado em estudos sobre raça e racismo no Brasil, em oposição a "negritude" (este sim com registro nos dicionários). O termo enfatiza a condição de ser branco e suas conotações ideológicas, acepção que os verbetes "branquidão" ou "brancura" não contemplam. (N. T.)

${ }^{2}$ Toni Morrison, Playing in the Dark: Whiteness and the Literary Imagination, New York, Vintage Books, 1993, p.3.

3 Richard Stang, The Theory of the Novel in England: 1850-1870, New York, Columbia University Press, 1959, p.192.

${ }^{4}$ Idem, ibidem, p. 192-3.

5 Thackeray Letters III, apud Stang, op.cit. 
Thackeray, o escritor primeiro é rebaixado à condição de estalajadeiro e depois à da estalagem em si, uma construção vazia que só ganha vida quando ocupada pela vitalidade dos personagens.

Se em um mundo pós-estruturalista e pós-moderno achamos estranho os romancistas do século XIX se sentirem governados por seus personagens, desejo alegar que isso se deve ao fato de que nosso conceito de alteridade se tornou mais abstrato, junto com nossas ideias sobre as relações de poder presentes na representação. O que me interessa particularmente no relato de Toni Morrison sobre a autoria é a clareza com que ecoa uma estética da alteridade no romance surgida ao longo do século XX. Pode-se verificar tal estética da alteridade na persistente sensação, partilhada por autores, leitores, críticos e paladinos da Teoria, de que o romance enquanto gênero se mostra altamente qualificado para oferecer um encontro com a outridade. Apesar da complexidade trazida à tona pelos estudiosos da narrativa para compreender os atributos da forma romance, e apesar de os modelos filosóficos de identidade terem mudado a noção de como os personagens podem e devem ser representados na fícção, subsiste a crença nos séculos XX e XXI de que os leitores devem e podem ser ensinados a prezar a alteridade oferecida pela leitura dos romances. O conceito de alteridade foi, obviamente, definido de modo diverso por diferentes escolas críticas. Porém, quer teorizado como o estado pétreo da pedra, o jogo literário da significação ou o inconsciente político, quer atribuído à diferença cultural do mundo ficcional, à capacidade técnica da ficção narrativa de representar outras mentes, à heteroglossia social da linguagem romanesca ou à natureza "antinatural" da ficcionalidade, o romance foi continuamente valorizado pelos teóricos e críticos do século XX pela capacidade privilegiada de "aproximar e conceitualizar a outridade". 6 Não importa se a fonte desse poder é definida como autor, autor implícito, narrador, roteirista, convenção social, política de classe, tecnologias de vigilância ou o real lacaniano: o que permanece firme no lugar, não somente para os escritores como também para muitos leitores comuns, críticos literários e elevados teóricos, é a convicção de que o romance dispõe de recursos narrativos para retratar tanto a condição e a qualidade da alteridade quanto a dinâmica do poder através da qual ela emerge e pode vir a ser conhecida. E, mesmo quando a conceitualização filosófica da alteridade é na melhor das hipóteses abstrata, o êxito ou o fracasso de determinado romance em representar a alteridade acaba sendo medido segundo os meios de que lança mão para representar sua gente ficcional como diferente do autor.

Observando mais detidamente a explicação de Morrison sobre a alteridade em relação aos personagens, vemos como sua descrição ao mesmo tempo parte do interesse oitocentista no efeito da autonomia descrito por Trollope e Thackeray e restringe a definição do encontro com a alteridade a personagens que não apenas são estranhos ao autor (no sentido de pessoas que para ele eram antes desconhecidas), como também estranhos em si: anticonvencionais, esquisitos, bizarros, até mesmo criminosos. Ao ler como escritora, Morrison valoriza

\footnotetext{
a forma como Homero descreve um ciclope devorador de corações, de modo que nossos corações se encham de pena; o modo como Dostoiévski induz a intimidade com Svidrigailov e o príncipe Míchkin. Fico assombrada com a autoridade do Benjy de Faulkner, da Maisie de James, da Emma de Flaubert, do Pip de Melville, do Frankenstein de Shelley...7
}

6 Jan Alber and Rudiger Heinze, Unnatural Narratives -Unnatural Narratology, Boston, Walter de Gruyter GmbH, 2011, p.2.

${ }^{7}$ Morrison, op.cit., p.4. 
O confronto com a autonomia do personagem, que para Trollope e Thackeray seria o encontro corporificado entre escritor e personagem ("o autor deve com eles discutir, brigar, deve perdoá-los e até mesmo submeter-se a eles"), para Morrison torna-se um evento psicológico e ético. A "relação plena de intimidade estabelecida" (Trollope) com os personagens de um romance é encarada por ela não como a tomada ruidosa da consciência autoral feita por um bando exigente de hóspedes barulhentos a quem o autor é subserviente, mas como o desejo ético desse autor de criar e habitar o ser de indivíduos cuja diferença em relação a si mesmo representa uma "desavença" tão profunda que, para ele, constitui quase uma diferença real de identidade. Para Morrison, a arte do romance está diretamente relacionada à disposição do autor de arriscar a "intimidade" (termo seu, assim como de Thackeray) com um outro cuja diferença em relação a si mesmo não é simplesmente (ou talvez nem seja) uma questão do número e da variedade de personagens que consegue imaginar, mas se localiza precisamente na "zona de perigo" que certos tipos de personagens representam para o escritor.8 Imaginar personagens verdadeiramente distintos de si é algo que, para Morrison, assume a forma do risco que ela sente de encontrar-se com eles. A medida do envolvimento com o outro como personagem é a ameaça que esse contato apresenta para o bem-estar do autor. $\mathrm{O}$ encontro do romancista com a alteridade do personagem é portanto, para Morrison, mais uma oportunidade profunda de autotransformação do que um serviço de hospedagem. Para o escritor, e para o leitor que lê como autor, "imaginar", afirma ela, "não é meramente olhar ou analisar; nem se colocar intacto dentro do outro. É, para os propósitos da obra, tornar-se". 9

Segundo Morrison, a atividade trabalhosa de tornar-se, permitida pelo romance, é tanto o desafio imaginativo de representar por dentro como é ser um criminoso, um assassino ou um louco quanto o encontro com os limites de conhecer o estranho, experimentado aí como a resistência do estranho a tornar-se familiar. À medida que Morrison desenvolve sua ideia de alteridade, percebemos que para ela o valor do personagem de romance reside tanto em sua fuga da representação "autoritária" quanto na intimidade alcançada pelo contato:

Estou interessada no que desencadeia e possibilita este processo de penetrar naquilo do qual se está apartado - e no que incapacita a incursão, para os propósitos da ficção, dos recantos da consciência mantidos fora do alcance da imaginação do escritor. ${ }^{10}$

O valor do estranhamento é multivalente na concepção de Morrison. Podemos entender um personagem ficcional como alguém diferente de nós mesmos por meio de um relato de seus atributos definidores, ou mesmo através do acesso que a ficção parece fornecer à sua interioridade privada - mas, para Morrison, a alteridade romanesca também é representada por aquilo que parece estar ausente da descrição que o autor faz do outro como personagem. Achar que um personagem não está plenamente construído, que ele resiste à representação plena, ao mesmo tempo demarca o limite da imaginação autoral e potencializa o efeito, no romance, de que os personagens já existiam anteriormente e estão além do controle ou conhecimento de seu criador. Considerar que um autor fracassou em apresentar o outro de forma plena é tanto creditar ao personagem uma identidade (uma consciência complexa, no exemplo de Morrison) que supera a imaginação autoral de alteridade, quanto chamar a atenção para valores autorais

\footnotetext{
${ }^{8}$ Idem, ibidem, p.3.

${ }_{9}$ Idem, ibidem, p.4. Ênfase no original.

${ }^{10}$ Idem, ibidem.
} 
através dos quais a descrição da "estranheza" é sempre avaliada como uma relação relativa. $\mathrm{O}$ que define a representação da outridade no romance, para Morrison, é não somente o encontro com um outro especificamente estranho - como um assassino, um louco -, mas também o encontro com a mais abstrata condição de incognoscibilidade, que permanece "fora do alcance" da imaginação.

Em Playing in the Dark, Morrison deseja manter abertas e múltiplas as fontes e manifestações da alteridade no romance. Porém, concentra-se de modo mais extenso no poder de uma identidade coletiva, chamado por ela de presença africanista, que invade "a mente, a imaginação e o comportamento dos senhores [brancos]". Tal como os personagens que ocupam a estalagem de Thackeray, a "presença africanista" é o hóspede que não se pode recusar. Contudo, ao contrário da experiência percebida do encontro do autor com o outro como personagem, a ideologia racial tece seu poder de outridade indiretamente. Agora, os recantos da consciência que estão "fora do alcance" da imaginação do autor são os do próprio autor.

Henry James foi, é claro, incluído na discussão de Morrison sobre a mecânica da ideologia racial. Ela aponta a descrição que James faz da "condessa americana" em Pelos olhos de Maisie como um exemplo fundamental de como a formação racial pode prejudicar a maestria narrativa até mesmo do mestre da narrativa. Morrison mostra que, embora James tenha escolhido uma vida londrina (tanto para si quanto para Maisie), não conseguiu escapar da sua formação ideológica de americano. E é precisamente a estranheza da condessa como presença no mundo ficcional de James - manifesta na combinação da natureza gratuita de sua identidade racial com a falta de especificação conferida a tal identidade no mundo fictício (ela é descrita no romance, pelo ponto de vista de Maisie, como "morena"/"brown") - que sinaliza sua função simbólica, de acordo com Morrison. Ela aponta que o encontro de Maisie com a condessa ocorre num momento crucial de tomada de decisão para a menina. Mas sua alegação de que a condessa "azeita a virada da trama e se transforma no instrumento da escolha moral e do significado em Pelos olhos de Maisie". ${ }^{11}$ só pode ser verdadeira quando se entende instrumento no elevado sentido simbólico de uma política racial que na realidade compromete a explícita representação, no romance, de escolha moral e ação ética, definidas na forma de relacionamentos interpessoais. Pois se a narrativa de James sugere haver uma relação entre o encontro de Maisie com a condessa e a decisão de Maisie de renunciar ao pai, mas não desenvolve nem esclarece a conexão causal entre esses dois atos, é porque o modo como os romances representam a função da alteridade ideológica é diferente de como a alteridade funciona no encontro entre os personagens. Enquanto expressão de ideologia racial, pode-se dizer que a influência da condessa atua por meio da mistificação que sua presença lança sobre as ações dos outros: a presença africanista se registra pela ilegibilidade que ela introduz na representação positiva da identidade e da ação social. A outridade africanista, portanto, faz-se presente não apenas na barreira que impõe à plena realização da identidade da condessa enquanto sujeito no mundo fictício (nas palavras de Morrison, o "aceno" que James lhe dá) como também no poder de dominar o mestre da ficção, ao produzir a "ruptura na lógica e na arquitetura da construção do enredo [de James]". ${ }^{12}$

\footnotetext{
${ }^{11}$ Idem, ibidem, p.13.
}

12 Idem, ibidem, p. 25 
Mas e quanto à própria Maisie? Por que Morrison a inclui na sua lista de estranhos bem realizados? Em que sentido Maisie está lado a lado com Svidrigailov, o príncipe Míchkin, o Benjy de Faulkner, a Emma de Flaubert, o Pip de Melville e o Frankenstein de Shelley? Se a condessa representa na narrativa a manifestação da alteridade na forma de um limite, de uma falha da representação, então que espécie de retrato bem realizado e "competente" de outridade pode-se dizer que Maisie representa? Estaria essa outridade, tal como a do príncipe Míchkin, em uma pureza moral tão radical a ponto de os adultos que rodeiam a menina a intitularem de "pequena idiota"? Ou seria Maisie de fato um "monstro moral", ombro a ombro com os ciclopes e Svidrigailov? Teria Morrison desejado demonstrar que James nos oferece uma estranha que, embora seja apenas uma menina de seis anos, possui certa afinidade com a "devassidão" e aceita a "depravação"13? A outridade de quem reside "no mal" que "era vertido dentro daquela alma tenra e atenta como se dentro de um recipiente sem fundo"14? Será Maisie uma devoradora de corações capaz de abrir o nosso próprio coração?

A partir de Playing in the Dark não é possível determinar qual a visão de Morrison sobre Maisie, entretanto desejo argumentar que as questões éticas levantadas pela representação que James faz de Maisie são cruciais para articular uma tradição anglo-americana da estética da alteridade. James esforça-se para alçar o romance a uma forma de arte elevada e, para isso, identifica os elementos formais e as faculdades próprias do gênero. Cena e quadro, o manejo do ponto de vista, o equilíbrio e a simetria do "tratamento" da história - essas são algumas das técnicas narrativas que lhe permitem teorizar o romance como uma forma verdadeiramente literária, distinta por princípios de arquitetura e composição e capaz de uma unidade estética bem realizada. Porém, ainda que James receba os créditos por ajudar a definir a arte do romance como um empreendimento estético, ele partilha a premissa de uma tradição realista anterior de que a raison d'être geral do romance é representar personagens "vivos". Quase todos os elementos de ficção identificados por James são recursos para intensificar a autonomia projetada da identidade dos personagens. George Elliot e Charles Dickens foram capazes de criar a ilusão de um meio social repleto de uma diversidade de personagens vivos e alcançaram esse efeito sem praticamente se preocupar em sistematizar seus métodos de representação. James simultaneamente aumentou a subjetivação da forma romance impregnando-a do ponto de vista dos personagens e depois fez dessa técnica formal a base da arte do romance. Assim, a teoria e a prática jamesianas da arte do romance introduziram a noção de que não apenas existem técnicas narrativas melhores e piores para retratar a autonomia dos personagens, como também que esses métodos compositivos colocam o autor em uma relação ética com seus personagens. Para James, a arte do romance é, portanto, inseparável de uma estética da alteridade que se fundamenta tanto na relação interpessoal implícita entre autor e personagem, estabelecida pela forma do romance, quanto na representação mimética dos próprios personagens como "outros" dotados de vida. Dessa maneira, a noção de que o romancista é servo do personagem que ele cria aparece inserida numa eticidade da composição, cujos fim e medida são representar os personagens como sendo diferentes do autor.

$\mathrm{Na}$ teoria e prática do romance jamesianas, é possível rastrear o investimento na

\footnotetext{
${ }^{13}$ Idem, ibidem, p.210 e 200.
}

${ }^{14}$ Idem, ibidem, p. 22. 
descoberta e nomeação não apenas dos elementos formais do romance, como também do espectro de emoções e atitudes em relação aos personagens, implicadas pelo uso de determinada técnica e não outra em determinada situação e não outra. O efeito da estética da alteridade jamesiana é tornar "viva" e palpável toda uma série de emoções e atitudes que se refletem, por sua vez, na relação ética do autor com seus personagens. Entre elas estão ironia, empatia, amor, identificação, alienação, mediação, instrumentalização, corrupção, contaminação, sedução, sacrifício e inclusive uma espécie de assassinato narrativo. É importante notar que, em James, a elaboração de uma ética da alteridade no romance não se baseia em uma filosofia ética sistemática que privilegia antecipadamente qualquer conexão emocional ou relação interpessoal específica em detrimento de outras. Desse modo, sua abordagem dos personagens difere da de críticos recentes que insistem, sobre uma base abstrata e filosófica, que certas emoções (como por exemplo a simpatia) inerentemente negam ou co-optam a alteridade da pessoa a quem a emoção se dirige. James, ao contrário, em relação a Maisie chega ao ponto de desenvolver uma técnica narrativa que a muitos parece representar a corrupção do caráter desse personagem. Quero levar essa imputação a sério porque acredito que os leitores e críticos que acusam James de por vezes tratar mal seus personagens chegando às raias do sadismo e da destruição - não são ingênuos; estão apenas reagindo de modo sensível à ética da alteridade que o próprio James incorpora em seus efeitos formais. Conforme discutirei a seguir, ao dar a impressão de corromper um personagem, o autor projeta de maneira poderosa a autonomia e independência desse caracterer que parece ser sua vítima. Entretanto, naturalmente apenas podemos afirmar isso se os romances tiverem estabelecido eles próprios, como um bem máximo, o direito de os personagens adquirirem vida própria.

As preocupações éticas dos mundos ficcionais de James ajudam-no a teorizar os tipos de alteridade que expressam estados de relações interpessoais forjadas através do posicionamento narrativo. Nossa percepção de como a pessoalidade alheia pode ser mais bem retratada no meio social dos romances jamesianos fornece uma medida dos métodos do autor para tornar real a pessoalidade de seus personagens. A discussão profunda nos romances jamesianos quanto à maneira correta de tratar os outros, quanto ao que uma pessoa pode "fazer" com outra, também nos encoraja a fazer perguntas filosóficas sobre quais qualidades e atributos os personagens de James estão "autorizados" a ter como "pessoas" de acordo com seu manejo formal. Quando encaramos os romances de James como uma exploração da natureza performativa da ética no mundo ficcional e através da sua conexão com a forma narrativa, quando entendemos que nossa percepção da realização estética de James vem carregada da análise ética estabelecida em seu mundo ficcional, podemos apreciar de modo diferente a arte do romance jamesiano - não como a composição perfeita, não como a ordenação abstrata do meio social por meio da unidade da forma estética, mas como a abertura ao julgamento ético e à emoção suscitados pelas técnicas narrativas do autor para imaginar a alteridade dos personagens. A representação do personagem não é algo que ocorre de modo conclusivo num romance de James: ela perpassa o romance como um todo, do início ao fim. A estética da alteridade jamesiana nos pede para registrar as modulações e desvios da técnica - por que esta determinada visão do personagem neste momento? - e atribuir tais registros de alteridade a um autor que é responsável pelo seu êxito ou fracasso ao fazer justiça para com o outro, ao imaginar o que a outridade deve ser e como ela pode ser mais eficientemente retratada. 
Pelos olhos de Maisie é um excelente ponto de partida para compreender como a estética da alteridade jamesiana funciona na prática. O que está em jogo no mundo ficcional é o problema exclusivo do tratamento ético da pessoalidade de Maisie. A questão moral colocada ao leitor é uma questão quase incessantemente articulada pelos próprios personagens do romance: haveria alguém no mundo ficcional eticamente qualificado para cuidar bem de Maisie? Algum adulto seria capaz de dar conta da obrigação social e jurídica - para não falar do dever natural - de proteger a menina das influências corruptoras? A condição de Maisie, de criança entre adultos, faz da representação jamesiana do direito dela à pessoalidade uma luta contra o contato social que constitui um molestamento espiritual (ou quase). A pequena Maisie encontrará protetores que a amarão pelo que ela é e que portanto reconhecerão sua singularidade enquanto ser ético? Ou será usada pelos adultos ao seu redor como um "pretexto", um "instrumento" para suas gratificações egoístas?

Esta é a questão ética que conduz a ação, e é parte da estratégia narrativa de James fazer com que sir Claude ofereça uma resposta no final do romance. Quando a sra. Wix o acusa de matar o senso moral incipiente de Maisie apenas para servir a seus próprios propósitos, ele responde: "Não matei nada". "(...) pelo contrário, creio que produzi vida. Não sei como chamála - nem sei como devo lidar com ela, abordá-la; mas, seja o que for, é a coisa mais bela que já vi - é magnífica, é sagrada". ${ }^{15}$

Notemos que sir Claude não afirma ter produzido um senso moral em Maisie. O que ele opõe aos lugares-comuns que englobam a moralidade convencional da sra. Wix é o bem absoluto da singularidade subjetiva. Ele acredita que seu amor por Maisie permitiu que surgisse nada menos do que a "vida" dela - uma existência valiosa em sua essencialidade e integridade, em sua liberdade da mácula das influências exteriores. Acreditar nessa interpretação sobre Maisie é concordar que o amor de sir Claude salvou-a de se transformar em um fantoche de ventríloquo ou no receptáculo do "mal" dos adultos. O tributo arrebatado de Claude a Maisie implica ademais que o bem que ele fez não está apenas no fato de ter permitido a Maisie conquistar o próprio ser, mas que esse seu ser exclusivo caracteriza-se por uma bondade intrínseca. O reconhecimento de Claude de que Maisie é bela, magnífica e até mesmo sagrada parece sustentar a opinião oferecida anteriormente no romance de que "o dom fatal da beleza" de Maisie é sua "beleza de caráter". ${ }^{16} \mathrm{O}$ assombro que Claude sente por Maisie neste momento da trama é portanto duplo: ele sente respeito pela autoridade da pessoalidade conquistada pela menina, uma vida que impõe reconhecimento ético próprio, ao mesmo tempo em que sente que o bem absoluto de ter uma vida aumenta com a qualidade dessa vida em particular: é isso que acredita ser a excepcional bondade de caráter de Maisie, ela ser a "criatura mais doce do mundo". ${ }^{17}$

A última palavra de Claude sobre Maisie não é, logicamente, a de James. Contudo, se a questão da excelência da pessoalidade de Maisie permanece em aberto, a declaração de Claude com certeza contribui para o registro ético de qualquer julgamento definitivo de como estimar o valor de Maisie como pessoa. Embora o romance em quase toda página levante a questão da

\footnotetext{
${ }^{15}$ Henry James, Pelos olhos de Maisie, trad. Paulo Henriques Britto, São Paulo, Companhia das Letras, Penguin, 2010 , p. 268 .

${ }^{16}$ Idem, ibidem, p. 98 .

${ }^{17}$ Idem, ibidem, p.96.
} 
condição moral da menina (será que ela é milagrosamente inocente ou sobrenaturalmente corrompida? Será que se tornará melhor ou pior?), esse problema de "ou isso ou aquilo" é apresentado através de uma espécie diferente de oposição ética: uma que coloca os bens da pessoalidade definidos como independência, definição de si e essencialidade (ou integridade) em oposição aos bens da dependência interpessoal, do amor correspondido e até mesmo da anexação subjetiva. Se o chegar de Maisie a si mesma é descrito por Claude como uma condição potencialmente "sagrada", o ser pelo outro é tido como o supremo bem social. James representa esse conflito de modo agudo na cena final entre Claude e Maisie. Se concordarmos com ele que Maisie chegou a si mesma, que se tornou quem é, essa conquista também marcaria o fim de uma dependência emocional que foi mutuamente gratificante e que, para Maisie, na verdade foi o que fez valer a pena viver uma vida, a sua vida. Pois o fato de Maisie tornar-se Maisie parece implicar que ela agora se situa fora, ou além, da condição de dependência emocional que foi exibida no romance como um estado tão raro e belo quanto qualquer outra condição de singularidade pode ser. James enfatiza a exclusividade mútua desses dois estados éticos - o ser para si e o ser pelo outro - acompanhando a homenagem de sir Claude à independência de Maisie com o que é descrito pelo narrador como o último ato de reciprocidade de ambos: "e trocaram um olhar de duas pessoas que fizeram uma pela outra o que puderam". O que vem em seguida só pode ser uma despedida final: "'Adeus', ele repetiu", ao que Maisie responde com seu próprio último adeus. ${ }^{18}$ Uma vez que sir Claude é a única pessoa no romance que amou Maisie pelo que ela é, essa despedida parece ser tanto o adeus ao estado ético de viver pelo outro quanto o desligamento de uma relação amorosa particular.

E quando notamos que no pequeno trecho de texto remanescente seguinte a essa despedida o ponto de vista de Maisie já não é mais retratado, que agora a estamos observando de fora, e, depois, na última frase do romance, pelo ponto de vista da sra. Wix, começamos a perceber como a técnica narrativa de James em Pelos olhos de Maisie alcança a condição de uma estética da alteridade. Parece haver uma relação motivada entre a transformação ética experimentada por Maisie e a forma como a menina é representada na narrativa. Alguns leitores poderão interpretar essa transformação como o feliz auge da autossuficiência de Maisie: ela agora se situa fora e além da sordidez de seu meio social. Outros poderão interpretar o desaparecimento do seu ponto de vista como o apagar final de seu espírito, privado agora da única conexão com a sociedade que ele conhecia. Mas por que o debate sobre o significado ético dessa manobra formal deveria encontrar uma solução mais fácil do que as outras questões éticas que James faz circular no mundo ficcional? Eu argumentaria na verdade que, do modo como James a desenvolve, a estética da alteridade se apoia - tal como a própria ambiguidade moral de Maisie (seria ela um anjo ou um demônio?) - na discussão que é capaz de inspirar. Discutir se o procedimento formal do final do romance representa o triunfo ou a tragédia da pessoalidade de Maisie já pressupõe que a forma da representação de Maisie vem investida de uma carga ética.

O prefácio de James para Pelos olhos de Maisie reforça que ele entende a arte do romance como uma tarefa ética. Ele afirma que sua intenção nesse romance é contar a história de Maisie unicamente do ponto de vista dela, oferecer-nos uma atuação vívida da "confusa e

${ }^{18}$ Idem, ibidem, p. 274. 
obscura notação da criança"19 da "transgressão" dos adultos ${ }^{20}$ que a rodeiam. James recorda que de início tencionava narrar a história do ponto de vista de Maisie, a fim de buscar o máximo de outridade: "limitar-me não só à experiência da criança como também à sua expressão verbal". ${ }^{21}$ No cerne desse projeto literário estaria o valor ético de trazer Maisie à luz (na forma de um personagem de romance) como pessoa dotada tanto de uma identidade intrínseca própria (enxergá-la de acordo com seus próprios termos) quanto de seu modo próprio de compreensão (pois ela enxerga por si mesma).

Porém, ao escolher contar a história do ponto de vista de uma criança pequena, ao assumir a responsabilidade de representar esse tipo particular de estranho, James imediatamente esbarra em obstáculos que evidenciam a diferença entre a sua consciência de adulto e a de uma criança. Como representar Maisie nos seus próprios termos linguísticos, quando as crianças têm uma linguagem tão pouco desenvolvida? James observa que, se permanecesse fiel à alteridade de Maisie como criança, o mundo visto pelos seus olhos conteria "na melhor das hipóteses (...) grandes hiatos e vazios, de modo que, por mais sistemática que fosse a superfície, faltaria clareza ao sentido". ${ }^{22} \mathrm{Em}$ outras palavras, se ele fosse completamente fiel ao ponto de vista de Maisie, só conseguiria representá-lo e nada mais perderia a base para transformar o ponto de vista em uma técnica capaz de retratar Maisie como um personagem inserido em um meio social.

James diz ter encontrado uma solução para essa dificuldade de representação: ela proviria de uma melhor compreensão da alteridade que define a subjetividade infantil. "As crianças", observa, "têm muitas percepções que não podem traduzir em palavras; sua visão é sempre muito mais rica, sua apreensão é constantemente mais forte do que seu vocabulário imediato ou não".23 Como então representar com o máximo de fidelidade a natureza linguística e intuitiva da percepção de Maisie? Além de usar as palavras dela, "pois que suas conclusões simplificadas delas dependem",24 James determina que traduzirá as percepções intuitivas de Maisie para seus próprios termos, que seu vocabulário e modo de expressão são na verdade o melhor veículo para expressar a riqueza e a complexidade da visão de mundo de Maisie.

(...) o que determina todo nosso interesse é a relação com a criança, é sua atividade mental; só que aproveitamos essas coisas melhor do que o faz ela própria. Porém, muito embora seja o interesse da criança o que mais determina o nosso interesse na questão, não podemos senão registrá-lo numa notação que ela ainda não domina, e que não obstante se torna necessária sempre que os aspectos a respeito de si própria e de sua experiência que ela compreende se fundem com as áreas mais obscuras que, para sua aflição, estão fora de seu alcance". ${ }^{25}$

Aqui a lógica de James o coloca em relação análoga à dos adultos do romance. Seria o cuidado linguístico de James uma espécie de entrega de si mesmo que autoriza Maisie a desabrochar o próprio ser? Por meio da subordinação bem-sucedida da presença dele no romance, será que o comprometimento de James com a "atividade mental" de Maisie permite

\footnotetext{
${ }^{19}$ Idem, ibidem, p.7

${ }^{20}$ Idem, ibidem, p.5

${ }^{21}$ Idem, ibidem, p.8.

22 Idem, ibidem, p.7.

${ }^{23}$ Idem, ibidem, p.8.

${ }^{24}$ Idem, ibidem.

${ }^{25}$ Idem, ibidem.
} 
que ele encontre o seu interesse no dela? James acredita que o uso da linguagem autoral é, como dizem os adultos na história, para o bem de Maisie. Acredita que seu comentário simplesmente evidencia para o leitor a rica complexidade de Maisie - que ele "intervém e amplifica" as percepções da criança. No entanto, será que a visão de Maisie pode tornar-se mais ampla e poderosa sem com isso ser também modificada? Será que a mente de Maisie pode continuar sendo dela mesma quando se parece tanto com a de James? Ou será o autor apenas mais um dos adultos que clamam, como sir Claude e a sra. Beale, fazer "dela seu dever - sua vida", ${ }^{26}$ mas cuja benevolência mal se distingue do molestamento?

O problema da relação de James com Maisie se torna ainda mais urgente devido às alegações maiores, no prefácio, de que a imaginação do artista pode ser um agente de melhoramento, e até mesmo de transformação, social. James afirma que teve a ideia inicial de Pelos olhos de Maisie quando soube "por acaso" da "situação de uma pobre criança, filha de pais divorciados" cujo destino foi virar alvo de uma disputa - primeiro de posse e depois de rejeição. James coloca para si mesmo a tarefa de tomar os fatos desagradáveis da situação e, pela "luz da imaginação", enxergar além do que de fato aconteceu na vida social para ver o que poderia ter acontecido: ver além, em suas palavras, da "degradação" da vida social moderna, a fim de trazer para a criança, através do seu romance, "a possibilidade (...) de felicidade e lucro". ${ }^{27} \mathrm{O}$ projeto estético do artista está, portanto, aliado à imaginação ética. Esta é definida como a capacidade de enxergar além da operação normativa de comportamento egoísta, a fim de postular a possibilidade e as condições para um florescimento humano. Pois transformar os fatos desagradáveis em "sutileza e riqueza" é, para James, o mesmo que imergir "a criaturinha (...) na segurança e no conforto"28 oferecidos pela intervenção ética dele. E, segundo James, o efeito transformador da imaginação ética do artista colocada em prol da criança apoia-se no valor ético inerente ao manejo artístico da composição e da forma do romance. Esses valores de "sutileza e riqueza"29 são algo que James também atribui à beleza formal alcançada: a arte metamorfoseia a vida a ponto de substituir os fatos desagradáveis pela "lógica elevada e firme" do projeto integrado, da "aplicação absolutamente definida e mensurável" que cria "a graça controladora" da integridade formal da obra de arte. ${ }^{30}$

Porém, embora o que mova o projeto representacional de Pelos olhos de Maisie seja a correspondência entre valor ético e valor estético, consideramos que a tentativa do prefácio de conciliá-los é uma fonte de tensão constante para James. Ao descrever por exemplo como pensou em desenvolver a trama de Maisie, ele apela para o valor formal da "simetria adequada" - e não para valores éticos adequados à capacidade subjetiva de Maisie de sentir segurança e felicidade. E, quando analisa o melhor meio de representar Maisie como personagem, trai a preocupação de que, caso exagerasse na "lógica elevada e firme" em termos de técnica narrativa, seu "tema seria sufocado" no "rigor extremo". 31 Ao ponderar quais efeitos seriam mais bem-sucedidos para levar a cabo o projeto do romance, James oscila entre o que seria

\footnotetext{
${ }^{26}$ Idem, ibidem, p. 90 .

27 Idem, ibidem, p.4.

${ }^{28}$ Idem, ibidem.

${ }^{29}$ Idem, ibidem.

${ }^{30}$ Idem, ibidem, p.8.

${ }^{31}$ Idem, ibidem, p.7.
} 
melhor para Maisie - o que traria para ela, segundo descreve, segurança e conforto - e o que seria melhor para o projeto artístico, ou seja, o que traria beleza e graça formais para o romance. O resultado é que muitas vezes o que parece conduzir a representação de Maisie é o desejo de produzir um efeito estético, conforme se vê na justificativa de James para limitar a experiência de Maisie aos atos sórdidos de adultos egoístas:

Se a criança (...) tecesse, com toda a boa-fé deste mundo, a trama densa da sofisticação; se a criança se tornasse centro e pretexto de um novo sistema de transgressão, sistema esse que, ademais, tenderia por sua própria natureza a espalharse e ramificar-se: esta a ironia "integral", este o tema promissor em que haveria de desabrochar logicamente o germe da ideia original. ${ }^{32}$

James justifica que insere Maisie em um meio social corrompido para retratar a superioridade ética intrínseca da menina em relação a esse mundo; superioridade essa que, segundo diz, não está apenas na incorruptibilidade da criança, mas também na sua capacidade de imaginar e realizar transformações sociais positivas. Isso equivale a dizer que James concede a Maisie uma capacidade ética semelhante àquela que atribuiu a si mesmo. Da mesma forma que deseja metamorfosear os fatos desagradáveis da vida social na sutileza e riqueza da possibilidade social, James atribui a Maisie uma imaginação "que opera maravilhas", a capacidade de criar futuros positivos por meio de seu "frescor", a expectativa integral de que, por mais que os adultos possam ser previsivelmente egoístas no mundo dela, também podem a qualquer momento demonstrar uma capacidade de generosidade e amor que lhe permitiria vêlos "além" (acima) das capacidades éticas deles. Conforme descreve James, Maisie portanto faz pelas pessoas do seu meio social o mesmo que ele tenta fazer por Maisie ao representar sua possibilidade subjetiva: "em vez de apenas submeter-se aos laços inatos e à complicação imposta, e sofrer tais condições, nosso pequeno agente miraculoso criaria, sem intenção, elementos novos dessa ordem (...)". ${ }^{33}$ (Podemos pensar no diálogo de Maisie com o capitão como um exemplo significativo.) O desabrochar ético de Maisie, conforme o concebe James, está portanto ligado ao risco social que ela corre: vem "ao preço de muitas convenções, e mesmo de preceitos morais", à medida que ela mantém "aceso o archote da virtude numa atmosfera que tudo faz para extingui-lo; em suma, no fundo tornando a confusão ainda pior ao introduzir uma leve fragrância de ideal em meio ao cheiro do egoísmo, ao semear em areias estéreis, pelo simples fato de sua presença, a semente de uma existência moral". ${ }^{34}$

Importante destacar: é a capacidade de Maisie de agir "sem intenção" que, segundo a concepção de James, permite-lhe permanecer isolada e distinta dos adultos manipuladores ao seu redor. E é precisamente a mistura de Maisie com a intenção artística de James que faz a tentativa dele de lhe dar "segurança e conforto" parecer, estruturalmente, as racionalizações hipócritas dos adultos que a exploram para seus próprios fins egoístas sob o pretexto de agirem para o bem dela. O "archote da virtude", que James alega implicitamente ser a fonte de sua própria capacidade de realizar, por meio da arte do romance, as transformações sociais que operam maravilhas, fica comprometido pelo tratamento instrumental dado a Maisie como

\footnotetext{
32 Idem, ibidem, p.5.

${ }^{33}$ Idem, ibidem.

${ }^{34}$ Idem, ibidem, p.6.

${ }^{35}$ Idem, ibidem, p.4.
} 
elemento funcional da forma. O prefácio de Pelos olhos de Maisie enfatiza a analogia entre James e Maisie, mas também enfatiza, por meio do deslocamento da metáfora do archote, como o projeto estético de James parece corromper seu projeto ético. A tentativa de James de conferir à representação ética da subjetividade de Maisie uma forma estética que contribua para o poder transformador de tal projeto ético resulta, em vez disso, na projeção do artista como alguém que explora a vida para seus próprios fins estéticos. O archote da virtude se transforma assim na "tocha do êxtase e da vitória, quando a mão do artista a empunha e brande". ${ }^{35}$

No prefácio, James lamenta os resenhistas que viram em Maisie apenas o que os termos de suas próprias identidades lhes deixaram ver. Cegos ao poder transformador da imaginação do ficcionista, esses primeiros resenhistas distinguem-se, segundo a ótica de James, pela falta de sensibilidade, pela incapacidade de enxergar de outra maneira; algo que em outros contextos Derrek Attridge chamou de incapacidade de se abrir ao novo, que leva à reprodução da ideocultura. James tem em mente resenhas como a que foi publicada em um periódico de Boston chamado Literary World, em 1897. O resenhista anônimo coloca o livro "no nível das piores escolas da ficção francesa", ${ }^{36}$ protestando tanto contra a "imoralidade" do comportamento dos personagens do romance quanto contra a imoralidade do próprio James por submeter Maisie a esse comportamento. E podemos ver nessa resenha de 1897 que o problema da conduta moral de James está diretamente relacionado ao seu manejo da forma narrativa. Para esse resenhista, James não consegue transformar os fatos desagradáveis que retrata porque seu propósito estético corrompe a relação que ele estabelece com Maisie. Segundo o resenhista de Boston, Henry James

não manifesta a menor piedade ou desânimo diante do espetáculo dessa criança, que tem a corrente pura de sua vida envenenada na fonte. Para ele, a menina é apenas a raison d'être de uma situação curiosamente complicada, que ele pode torcer e distorcer para os fins de sua ficção. Sente-se, no decorrer da leitura, que todo sentimento viril, toda possibilidade de empatia generosa, toda compreensão dos padrões mais elevados, tornaram-se atrofiados na natureza do sr. James por falta de uso, e que toda e qualquer relação entre ele e seus semelhantes pereceram, senão com o fim de lhe servir, friamente, de "material". ${ }^{37}$

No centro das críticas desse resenhista está a suposição de que um personagem de certo modo não faz parte do material do autor, de que os personagens merecem um tratamento representacional diferenciado com base no seu estatuto de pessoa, e que para representar pessoas deve-se prover-lhes segurança e conforto - tanto na forma de uma crítica explícita do autor contra aqueles que desejam explorar Maisie quanto em um "sentimento viril" indiretamente sugerido, aqui interpretado como a simpatia do autor masculino para com os apuros de seu personagem. Para o resenhista, o fato de James não estar presente de nenhum desses dois modos no meio social de seu romance indica como sua longa carreira artística simplesmente o alienou da vida social tout court. Segundo essa perspectiva, a dedicação à arte durante toda uma vida é o que sufoca a ética da alteridade. A ela atribui-se um poder corruptor, pois não apenas retira James do meio social que ele deseja retratar, ao trancafiá-lo em seu gabinete, como também faz com que ele enxergue esse meio de um modo instrumental, apenas

\footnotetext{
${ }^{36}$ Idem, ibidem, p. 294.

${ }^{37}$ Idem, ibidem, p. 238.
} 
para atender ao projeto estético ao qual pode servir. A realização do projeto estético de James é assim reduzida por esse resenhista à sua intencionalidade. Em vez de usar a ficção para cultivar as relações sociais entre "ele e seus semelhantes", James desenvolve a mão firme que empunha e brande seus personagens, deixando assim de tratá-los como as pessoas que poderiam ser.

É tentador rechaçar esse crítico contemporâneo como um leitor não sofísticado cuja reclamação contra James se baseia numa reação excessivamente crédula à mimese fíccional. Um século depois, porém, vemos críticos do autor, muito bem informados pela teoria literária pós-estruturalista, vociferando acusações ainda mais enfáticas contra o caráter moral de James, com base numa suposta ética dos autores no tratamento dos seus personagens de ficção. Vejamos Sheila Teahan em sua análise de 1990 sobre Pelos olhos de Maisie:

O conhecimento ambíguo de Maisie e sua transformação final em bode expiatório (...) são produtos da estratégia jamesiana de representação da inteligência central, que tanto dá Maisie à luz quanto a sacrifica em nome de sua própria lógica antitética. ${ }^{38}$

Teahan, tanto quanto o resenhista de Boston, entende o projeto estético de Pelos olhos de Maisie como fundamentalmente oposto à representação ética da subjetividade de Maisie. Para ela, a manifestação do estetismo explorador reside na devoção equivocada à intenção lógica, o que leva James a construir sua protagonista como um ponto de vista, acreditando que dessa maneira a representação da consciência singular de Maisie pode também servir convenientemente de elemento formal. Tanto para Teahan quanto para o resenhista de Boston, a palpabilidade da função formal de Maisie no romance remonta à limitação ética de seu criador: expõe o que Teahan chama de "senso moral questionável" de James ${ }^{39}$ - e para ela isso é ainda mais extremo do que para o resenhista de Boston: Maisie não somente "serve friamente" a James, como "perece".

É possível, entretanto, ver como no prefácio do romance (onde descreve o problema estético que colocou a si mesmo) James relaciona problematicamente uma questão nova para a tradição anglo-americana, o problema de desenvolver uma arte do romance, com a representação da alteridade que define o valor social da arte. Em outras palavras, o próprio James, tanto nos textos sobre o romance como forma quanto nas formas que seus romances assumem, ajuda a estabelecer as bases éticas para os ataques ad hominem a ele perpetrados tanto por leitores antigos quanto recentes. Ao refinar as técnicas de representação dos personagens como sujeitos autônomos, James também estabeleceu a arte do romance como uma força hostil ao meio social que ele projeta. Se o escritor consegue mascarar seus próprios objetivos artísticos, arrisca-se a ser acusado de cumplicidade ideológica, de "esconder os poderes e interesses que permeiam essa prática significativa". ${ }^{40}$ Se James torna seus objetivos palpáveis, pode tanto ser elogiado por haver conseguido transformar a norma, celebrado como foi por Judith Butler por frustrar ou desmontar o quadro de referências epistemológicas do leitor, quanto ser acusado, como o foi por Adam Zachary Newton e uma multidão de outros críticos, por não conseguir presentificar a "singularidade" da subjetividade dos personagens.

\footnotetext{
38 Sheila Teahan, "What Maisie Knew and the Improper Third Person", Studies in American Fiction 21.2 (1993), p.127.

${ }^{39}$ Idem, ibidem, p. 137.

${ }^{40}$ Bruce Robbins, The Servant's Hand, p. 7, apud Derek Attridge, J.M. Coetzee and the Ethics of Reading:

Literature in the Event, Chicago, University of Chicago Press, 2004.
} 
Mais uma vez, o que desejo não é argumentar que a crítica ideológica ou a nova crítica ética está certa em relação ao valor da leitura dos romances, nem mesmo que um crítico levinasiano está certo e o outro está errado.

No projeto do meu livro do qual esta palestra deriva, meu objetivo é retomar o papel que James e outros romancistas do século XX desempenharam em promover o entendimento da forma romance como um embate entre a representação da alteridade e as forças sociais que comprometem, inibem ou extinguem tal representação. Ao nos dirigirmos à história literária, que com tanto empenho investiu a forma romance do valor ético da alteridade, descobrimos que o empreendimento realista do oitocentos, de criar "outros dotados de vida", continua bem vivo - ainda que no século XX os romancistas tenham mudado nossa noção de onde, e como, esse efeito de alteridade pode ser mais bem produzido.

Tradução: Ana Carolina Mesquita

Revisão da tradução: Marcelo Pen Parreira

\section{Bibliografia}

ALBER, Jan and Rudiger Heinze, eds. Unnatural Narratives -Unnatural Narratology. Boston: Walter de Gruyter GmbH, 2011.

ATTRIDGE, Derrek. J.M. Coetzee and the Ethics of Reading: Literature in the Event. Chicago: University of Chicago Press, 2004. Bruce Robbins, The Servant's Hand, p. 7, citado em Attridge.

The Singularity of Literature. New York: Routledge, 2004.

BUTLER, Judith. "Values of Difficulty," Just Being Difficult? Academic Writing in the Public Arena, ed. Jonathan Culler and Kevin Lamb. Stanford: Stanford University Press, 2003, pp.199-215.

HAYs, Kevin J. Henry James: The Contemporary Reviews. New York: Cambridge University Press, 1996. Resenhista anônimo da Literary World citado em Hays.

JAMES, Henry. What Maisie Knew. New York: Oxford World's Classic, 2008. 1993.

MORRISON, Toni. Playing in the Dark: Whiteness and the Literary Imagination. New York: Vintage Books,

NEWTON, Adam Zachary. Narrative Ethics. Cambridge: Harvard University Press, 1995.

STANG, Richard. The Theory of the Novel in England: 1850-1870. New York: Columbia University Press, 1959. Anthony Trollope e William Makepeace Thackeray citados a partir de Stang.

TEAHAn, Shelia. "What Maisie Knew and the Improper Third Person". Studies in American Fiction 21.2 (1993): 127-40. 